\title{
AREA-WIDE MANAGEMENT OF RICE PLANTHOPPER PESTS IN ASIA THROUGH INTEGRATION OF ECOLOGICAL ENGINEERING AND COMMUNICATION STRATEGIES
}

\author{
K. L. HEONG ${ }^{1,6}$, Z. R. ZHU ${ }^{1}$, Z. X. LU ${ }^{2}$, M. ESCALADA ${ }^{3}$, \\ H. V. CHIEN ${ }^{4}$, L. Q. CUONG ${ }^{5}$ AND J. CHENG ${ }^{1}$ \\ ${ }^{1}$ Institute of Insect Sciences, Zhejiang University, Zijingang, Hangzhou, China; \\ klheong@yahoo.com \\ ${ }^{2}$ Institute of Plant Protection and Microbiology, Zhejiang Academy of Agricultural \\ Sciences (ZAAS), Hangzhou, China \\ ${ }^{3}$ Visayas State University, Baybay, Leyte, Philippines \\ ${ }^{4}$ Plant Protection Department, Mekong University, Vinh Long, Viet Nam \\ ${ }^{5}$ Southern Regional Plant Protection Center, Long Dinh, Tien Giang Viet Nam \\ ${ }^{6}$ Formerly at the International Rice Research Institute (IRRI), Los Baños, \\ Philippines
}

\begin{abstract}
SUMMARY
Most rice insect pests are exogenous immigrants from either long distances or neighbouring areas. For their management to be economical and sustainable, an area-wide perspective is imperative. Key pests, like the planthoppers and stem borers, are highly dependent on rice for survival and reproduction. They multiply and move from one rice crop to another, sometimes carrying virus diseases such as ragged stunt, grassy stunt and rice stripe from source areas. The planthoppers are $r$ strategists, unable to overwinter in northern China, Japan and Korea, and are known to "migrate" or are displaced by wind from southern China to temperate regions of China, Japan and the Korean peninsula. With adequate faunal biodiversity and biological control ecosystem services in a rice crop, immigrant pests have low chances of survival and growth capacities, and often remain a minor pest. However, when the local ecosystem services are compromised, often by unnecessary insecticide use or extreme weather conditions, such as droughts or floods, the immigrants show high survival and growth rates. Since, 2008 the Rice Bowl of Thailand suffered brown planthopper (BPH) (Nilaparvata lugens Stål) outbreaks for 14 consecutive rice seasons that caused
\end{abstract}

J. Hendrichs, R. Pereira and M. J. B. Vreysen (eds.), Area-Wide Integrated Pest Management: Development and Field Application, pp. 617-631. CRC Press, Boca Raton, Florida, USA.

(C) 2021 IAEA 
losses of more than USD 200 million. Farmers were routinely applying insecticides as prophylactics and the BPH consequently "escaped" its natural control and populations increased 100000 -fold. Ecological engineering approaches involve practices that will build and restore biodiversity and ecosystem services, and reduce insecticide-induced threats to ecosystem services. An area-wide increase in floral biodiversity in the crop landscape provides shelter, nectar, alternate hosts and pollen (abbreviated as SNAP by Professor Wratten) to conserve the natural enemy fauna. Pioneered in Jin Hua, China with sesame plants grown on the rice bunds, ecological engineering is now practiced in China, the Philippines, Thailand, and Viet Nam, using several flower species. A multi-country, multi-year field trial conducted by scientists of the International Rice Research Institute (IRRI) in collaboration with researchers from Australia, China, Thailand and Viet Nam showed that the growing of flowers on rice bunds as an ecological engineering practice increased profits (by $7.5 \%$ ), yields (by $5 \%$ ), biological control (by $45 \%$ ) and added aesthetic values to the rural landscape. At the same time the ecological engineering practice decreased insecticide use (by $70 \%$ ), pest densities (by 30\%) and farmers' chemical input costs (by 70\%). Farmers are adopters and implementers of ecological engineering practices, and to reach and motivate the millions of farmers in Viet Nam, two TV serials developed using entertainment-education principles were launched to promote the establishment of flower strips and to reduce insecticide applications. The TV serials helped farmers to "see" and appreciate the role of parasitoids by linking these (termed locally as "small bees") to widely-known bees. Farmers that viewed the serials decreased their insecticide use by $24 \%$, had $3.3 \%$ higher yields, increased their appreciation of parasitoids and gained positive attitudes towards the establishment of flower strips. To achieve sustainable area-wide pest management, ecological engineering practices have to be coupled with rational pesticide management through better pesticide policies, regulations and implementation, accurate pest diagnostics and timely professional advice to farmers. Aside from its proven impacts on pest control and more profitable farming, increasing biodiversity and ecosystem services in rice fields can also contribute towards climate change adaptation and a more resilient environment.

Key Words: Nilaparvata lugens, brown planthopper, rice, rice insect pests, ecosystem services, migration, mass-media, entertainment-education, habitat manipulation, biological control, natural enemies, parasitoids, predators, China, Philippines, South Korea, Thailand, Viet Nam

\section{INTRODUCTION}

Rice is the staple food for more than 3000 million people, grown on 159 million hectares (ha) in most Asian countries (IRRI 2013). It is often believed that insect pests are major constraints as there are hundreds of herbivore species that can potentially attack various parts of the rice plant (Heinrichs 1994). However, in reality only a few species are key pests that can cause economically-significant yield loss and among these, most species are either monophagous or oligophagous, and are highly dependent on rice for survival (Way and Heong 1994).

Besides herbivores, there are hundreds of predator, parasitoid and detritivore species that are beneficial to the rice ecosystem (Heong et al. 1991). The most destructive pests are the planthoppers, which are $r$ strategists capable of multiplying rapidly. They damage crops directly by sucking, causing a symptom known as "hopperburn" and by transmitting virus diseases (Heong and Hardy 2009). Unable to overwinter and strictly monophagous, the planthoppers migrate or are displaced by winds over long distances from maturing fields to new rice crops, often from northern regions of Viet Nam and southern China to central and northern China, Japan and the Korean peninsula (Watanabe et al. 2009). 
The biodiversity of predators and parasitoids present in rice ecosystems is usually adequate to limit the growth of these migratory pests. However, when the faunal biodiversity that provides the biological control ecosystem services are compromised and the immigrant populations are abnormally high, they can reach outbreak proportions.

Since 2008 the Rice Bowl of Thailand suffered brown planthopper (BPH) (Nilaparvata lugens Stål) outbreaks during 14 consecutive rice seasons, causing losses of more than USD 200 million (Heong et al. 2015a). Thailand's rice farmers had been routinely applying insecticides as prophylactics, primarily cypermethrin and abamectin, thereby killing natural enemies and as a result the BPH "escaped" its natural control and populations increased unchecked by more than 100000 -fold in just 2 months. At the same time, similar BPH outbreaks were also reported in Java, Indonesia caused by similar insecticide misuse (Fox 2014).

\subsection{Biological Control Ecosystem Services}

Ecosystem services are benefits that people obtain from ecosystems (MEA 2005). Biological control ecosystem services are among the regulatory services derived from predation and parasitism activities, delivered by a diverse and abundant complex of predator and parasitoid species present in the agroecosystem.

Tropical rice ecosystems are richly endowed with these predatory and parasitoid species that play significant roles in keeping the number of pest species low (Way and Heong 1994). As a consequence, the pest species rarely cause economicallysignificant damages, and even in intensified rice crops, insecticides are not regularly needed (FAO 2011).

\subsection{Are There Productivity Gains from Farmers' Insecticide Usage?}

Researchers have been questioning whether farmers' insecticide use, as promoted in the 1970s and 1980s under the Green Revolution, have had any productivity gains in rice (Heong et al. 2015c). Insecticides packaged together with fertilizer have been applied as prophylactics based on calendar schedules, and this practice has remained entrenched in most of Asian countries (Heong and Escalada 1997; Escalada et al. 2009).

Typically rice farmers would conduct overhead sprays in the early crop stages, using locally-made spray equipment with poor spray delivery. Most of these sprays do not impact the target pests and often roll off the rice plants into the water. One study found that more than $80 \%$ of rice farmers' sprays were found to be misuses of insecticides that resulted in no yield gain (Heong et al. 1995).

A replicated field plot experiment conducted by economists to assess cost-benefits from different pest management strategies found that fields with zero insecticide sprays offered the best option, while net losses increased with the number of insecticide sprays (Table 1) (Pingali et al. 1997). 
Table 1. Comparison of insecticide spray strategies of farmers in 2 sites in the Philippines (after Pingali et al. 1997)

\begin{tabular}{|c|c|c|c|}
\hline Sites & Management strategies & $\begin{array}{l}\text { Number of } \\
\text { sprays }\end{array}$ & $\begin{array}{c}\text { Percent net } \\
\text { benefits over "no } \\
\text { spray" }\end{array}$ \\
\hline \multirow[t]{4}{*}{ Laguna } & Complete protection & 6 & $-11.7 \%$ \\
\hline & Farmer's strategy & 2 & $-3.6 \%$ \\
\hline & $\begin{array}{l}\text { Integrated Pest } \\
\text { Management }\end{array}$ & 1 & $-5.0 \%$ \\
\hline & No spray & 0 & $-0.0 \%$ \\
\hline \multirow[t]{4}{*}{ Nueva Ecija } & Complete protection & 6 & $-4.7 \%$ \\
\hline & Farmer's strategy & 2 & $-3.1 \%$ \\
\hline & $\begin{array}{l}\text { Integrated Pest } \\
\text { Management }\end{array}$ & 1 & $-3.5 \%$ \\
\hline & No spray & 0 & $-0.0 \%$ \\
\hline
\end{tabular}

Moreover, yield-insecticide application relationships from 8 farm survey data-sets showed that average yields of farms, where no insecticides were used, did not differ from those with 3 or more sprays (Heong et al. 2015b).

In farmer participatory experiments, where farmers divided their fields into 2 plots, i.e. one that would not receive any sprays in the first 40 days after sowing and the other with normal practices, yields of the plots with reduced insecticide sprays were slightly higher (Huan et al. 2005). The prophylactic insecticide sprays, especially in the early crop stages, tended to destroy the biological control ecosystem services (Heong 2009) and increased subsequently crop vulnerability to planthopper outbreaks by about ten-fold (Heong et al. 2015b).

\subsection{Ecological Engineering in Rice}

Pioneered in China ( $\mathrm{Lu}$ et al. 2015), ecological engineering in rice entails the promotion of insecticide reductions and the establishment of (nectar-rich) flowering plants on the bunds and field margins, with the ultimate goal to restore biodiversity and ecosystem services (Fig. 1). 
The flora on the bunds provides shelter, nectar, alternate hosts and pollen (abbreviated SNAP) to conserve the natural enemy fauna and associated biological control services (Gurr et al. 2012). For instance, parasitoids of planthoppers live on alternative hosts on the bunds (see review by Gurr et al. 2010), crickets that are predators of pest eggs breed in bund habitats with the grass Bracharia mutica (Forssk.) Stapf and forage in rice fields at night (Kraker et al. 1999), and spiders also use such habitats for shelter and breeding. Coupled with withholding insecticide sprays in the early crop stages, biological control services are further enhanced through ecological engineering.

A multi-country and multi-season replicated field experiment in China, Thailand and Viet Nam showed that rice fields with flower strips as an ecological engineering practice required less insecticides (by 70\%), had increased yields (by 5\%) and profits (by $7.5 \%$ ). In addition, the fields had increased biological control (by $45 \%$ ), and lower pest abundances (by 30\%) (Gurr et al. 2016).

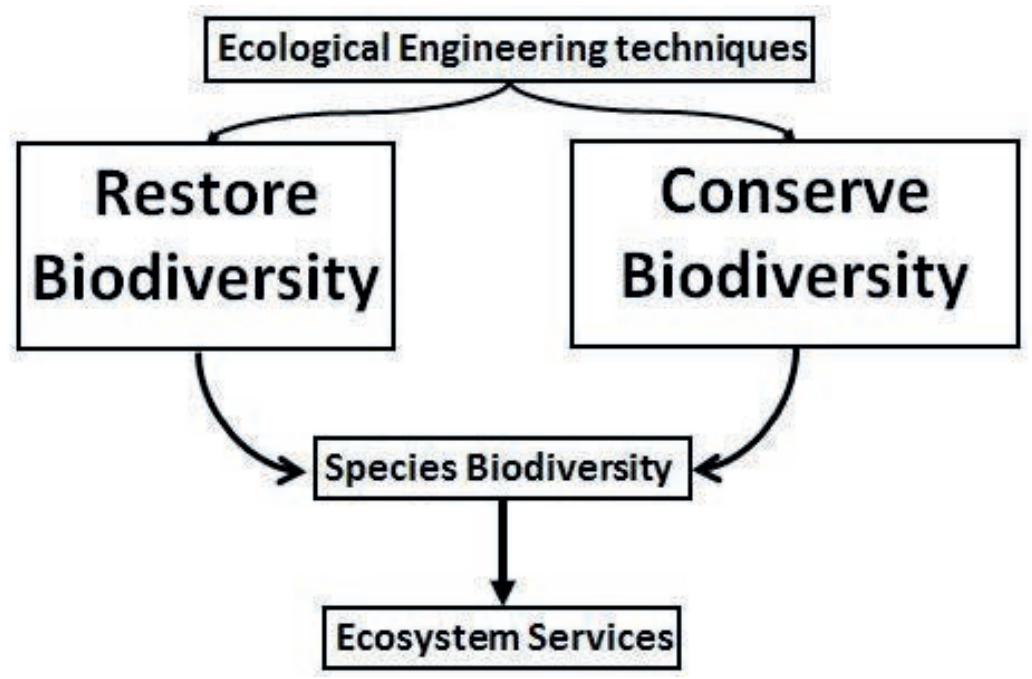

Figure 1. Ecological engineering techniques both restore and conserve biodiversity and ecosystem services (modified from Heong et al. 2014).

Another technique is to grow a trap-plant like vetiver grass (Vetiveria zizanioides (L.) Nash) on bunds before crop establishment. The grass will attract striped rice stemborer (Chilo suppressalis (Walker) females to lay eggs on the leaves of vertiver grass, but the larvae will not survive on them (Lu et al. 2017; Zheng et al. 2017).

In rice fields in Indonesia, Ives and Settle (1997) also recorded increases in natural enemy populations in asynchronous planting, where early-arriving generalist predators decimate incipient infestations of pests and suppress their populations. 


\section{AREA-WIDE IMPLEMENTATIONS OF ECOLOGICAL ENGINEERING PRACTICES}

Most rice pests and especially the planthoppers are highly mobile, primarily monophagous, and the adults invade new rice crops from other fields. In order to manage such pests sustainably, control strategies need area-wide implementation. In Southeast Asia the size of most farms is small (less than 2 ha) and so a typical rice growing area, like the Mekong Delta, would easily be managed by about a million decision-makers.

To successfully implement ecological engineering practices in such large areas, there is a need to understand farmer decisions in order to help design communication strategies that can reach and motivate all of these decision-makers.

\subsection{Understanding Farmer Decisions}

In a series of social psychology studies to understand rice farmers' pest management decision-making, a psychometric model was developed (Escalada et al. 2006; Escalada and Heong 2012). In making resource management decisions, farmers are always faced with uncertainty, limited time and knowledge, and like most people they use the "satisficing" strategy rather than making decisions that would be maximizing outcomes (Simon 1982).

Farmers generally use "heuristics" (or rules of thumb) under conditions of limited time, knowledge and computational capacities. However, heuristics that farmers have developed through experience and guesswork about possible outcomes might have inherent faults and biases. Research to understand farmers' heuristics and their reasoning can help in developing communication strategies to frame alternative heuristics that can improve their decisions.

\subsection{Designing Communication Strategies}

Two mass-media based communication strategies, found to be effective in promoting pest management practices, were used to reach farmers and motivate their adoption of ecological engineering practices: multi-media campaigns and entertainmenteducation series on TV.

\subsubsection{Multi-media Campaigns}

Mass-media campaigns to motivate rice farmers to change practices have been highly successful in Viet Nam. The campaign to reduce early-season spraying has helped in easing farmers' loss aversion attitudes and consequently in lowering insecticide sprays by $53 \%$ (Heong et al. 1998; Escalada et al. 1999). 
In a follow-up campaign, advocating farmers to reduce insecticide sprays, seed and fertilizer rates (locally named "Three Reductions"), farmers lowered their seed and fertilizer use by $10 \%$ and $7 \%$ respectively and their insecticide sprays by $33 \%$ (Huan et al. 2008).

In each of the campaigns a multi-stakeholder participatory planning and review process involving research, extension, mass-media, universities and local governments was used to develop materials and plan further media strategies (Heong et al. 2010). Prototype posters and leaflets for the ecological engineering campaigns were developed using the same process and were pre-tested before they were massproduced and distributed. Fig. 2 shows examples of the posters used in Viet Nam and China to promote ecological engineering practices.
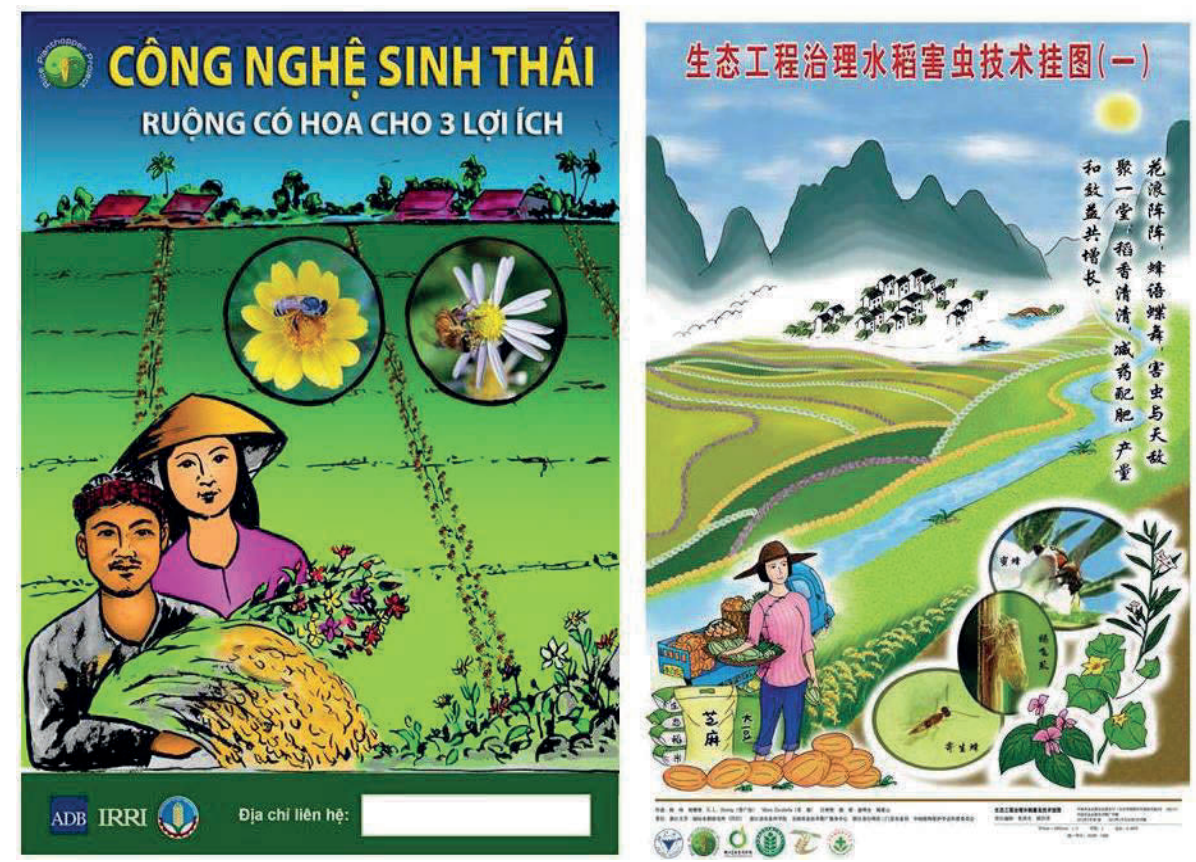

Figure 2. Posters developed for distribution to promote ecological engineering techniques in Tien Giang Province, Viet Nam (left) and San Men, China (right) (credits K. L. Heong and Z. R. Zhu).

In a post-campaign survey, conducted 8 months after the campaign launch in Viet Nam, significant changes in farmers' key beliefs related to ecological engineering were recorded (Table 2).

\subsubsection{Entertainment-education on $T V$}

Entertainment-education is the process of designing and implementing a programme to both entertain and educate so as to increase target audience members' knowledge, 
create favourable attitudes, shift norms and change behaviour (Singhal and Rogers 1999). A radio soap opera using this process to motivate change in farmers' pest management resulted in a reduction in insecticide sprays by $60 \%$ among the listeners (Heong et al. 2008).

Table 2. Changes in key beliefs related to ecological engineering before and after the massmedia campaign launch in Tien Giang Province, Viet Nam (after Heong et al. 2014)

\begin{tabular}{|l|c|c|c|}
\hline \multirow{2}{*}{ Key belief items in Ecological Engineering } & \multicolumn{2}{|c|}{$\begin{array}{c}\text { Percent farmers } \\
\text { believing to be "always } \\
\text { true" }\end{array}$} & \multirow{2}{*}{$\begin{array}{c}\text { Percent } \\
\text { change }\end{array}$} \\
\cline { 2 - 3 } & Pre & Post & \\
\hline Flowers on bunds attract bees and parasitoids & 45.9 & 56.3 & +22.7 \\
\hline $\begin{array}{l}\text { Flowers on bunds are homes for spiders and natural } \\
\text { enemies }\end{array}$ & 31.1 & 43.9 & +41.2 \\
\hline Flowers on bunds help us reduce insecticides & 39.8 & 50.3 & +26.4 \\
\hline Flowers on bunds help reduce BPH outbreaks & 27.4 & 41.1 & +50.0 \\
\hline
\end{tabular}

To upscale the adoption of ecological engineering practices, a TV serial of 40 episodes, broadcast on Vinh Long TV twice a week was launched (Heong et al. 2014). Of the 593 farmers interviewed after the broadcast, about $41 \%$ had not watched any of the TV serial episodes (non-viewers). Of those who had watched the TV serial, most farmers $(60 \%)$ watched five or fewer episodes and only $7 \%$ had watched more than fifteen episodes. Farmers who had viewed the TV serial sprayed significantly less insecticides (19\% less), used less nitrogen fertilizer (6\% less), and used lower seed rates $(12 \%$ less). The yields of viewers were marginally higher than those of nonviewers (difference of $0.2 \mathrm{t} / \mathrm{ha}$ ). Farmers who had watched the TV serial could recall what they learned from the series.

Table 3 shows the most common lessons farmers cited. There were significantly more farmers believing in statements that favour ecological engineering among the viewers than the non-viewers (Table 4).

\section{CONSTRAINTS TO AREA-WIDE IMPLEMENTATION OF ECOLOGICAL ENGINEERING}

While numerous research studies have demonstrated various successful methods and approaches, including ecological engineering, for reducing insecticide use in rice production, most of these have not been sustainable or adopted at an area-wide scale. Insecticide use in rice has continued to escalate despite the research showing that there are few or no productivity gains (Heong et al. 2015c) and that insecticides induce outbreaks of secondary pests like the planthoppers, that are more damaging (Bottrell and Schoenly 2012; Heong and Schoenly 1998).

The well-funded Farmer Field School (FFS) approach of the Food and Agriculture Organization of the United Nations (FAO), that trained millions of rice farmers in 
integrated pest management (IPM) (Matteson 2000), had indeed some successes. Graduates of FFS benefited from a statistically significant gain in knowledge of better pest management. However, such knowledge did not diffuse to other members of their villages (Feder et al. 2004). When the programme ended in Indonesia by the late 1990s the gains were rapidly lost (Thorburn 2013), insecticide use once again escalated, and insecticide imports increased by more than 5000\% (Heong et al. 2015b).

Table 3. TV serial viewers' recalls of what they had learned from it (Heong et al. 2014)

\begin{tabular}{|l|c|}
\hline \multicolumn{1}{|c|}{ What farmers learned from the TV serial } & \multicolumn{1}{|c|}{$\begin{array}{c}\text { Percent farmers } \\
\text { recalling* }\end{array}$} \\
\hline Nectar flowers can attract natural enemies to help pest control & 29.9 \\
\hline Nectar flowers can help reduce insecticide use & 14.8 \\
\hline Flowers on the bunds can help protect the environment & 11.3 \\
\hline Flowers help the beautify the rural landscape & 10.1 \\
\hline Applying "3 reductions" methods & 13.3 \\
\hline If insecticides are to be used, apply them correctly & 11.9 \\
\hline Techniques in flower growing & 9.6 \\
\hline
\end{tabular}

* Multiple responses

Table 4. Key beliefs related to ecological engineering practices and comparison between viewers and non-viewers of the TV serial in percent of farmers who said that the statements were "always true" (Heong et al. 2014)

\begin{tabular}{|c|c|c|c|}
\hline \multirow[t]{2}{*}{ Belief statements } & \multicolumn{2}{|c|}{$\begin{array}{c}\text { Percent farmers who believed } \\
\text { the statement to be "always } \\
\text { true" }\end{array}$} & \multirow[t]{2}{*}{$\chi^{2}$} \\
\hline & Viewers & Non-viewers & \\
\hline $\begin{array}{l}\text { Flowers on bunds can attract bees and } \\
\text { parasitoids to protect rice }\end{array}$ & 32.2 & 21.1 & $25.7^{* *}$ \\
\hline $\begin{array}{l}\text { Flowers on bunds are homes for spiders and } \\
\text { other predators }\end{array}$ & 35.9 & 21.5 & $30.6^{* *}$ \\
\hline $\begin{array}{l}\text { Flowers on bunds help farmers reduce } \\
\text { insecticide use }\end{array}$ & 37.6 & 21.1 & $24.8^{* *}$ \\
\hline $\begin{array}{l}\text { Flowers on bunds can help reduce } \\
\text { planthopper pest outbreaks }\end{array}$ & 30.8 & 19.8 & $13.2^{*}$ \\
\hline $\begin{array}{l}\text { Flowers on bunds make rice landscapes } \\
\text { beautiful }\end{array}$ & 68.3 & 55.4 & $19.6^{* *}$ \\
\hline
\end{tabular}

$\chi^{2}$ Chi Squared: * significant at 0.05\%; ${ }^{* *}$ significant at $0.01 \%$ 
Besides developing innovative pest management methods, the major constraints to adoption that need to be addressed are the weak regulations regarding insecticide marketing and the shortage of extension and field staff with knowledge and pest diagnostic capacities.

\subsection{Pesticide Marketing in Asia}

Using the "driving forces, pressures, states, impacts, responses" (DPSIR) analytical framework, Spangenberg et al. (2015) highlighted that the weak regulation of pesticide marketing is the root cause for the unsustainable implementation of ecologically-based practices. In Asia, the use of insecticides in rice is not driven by pest pressures but attributed mainly to the aggressive marketing strategies of insecticide companies, similar to those used to promote fast-moving consumer goods (FMCGs) (Heong et al. 2015b). Pesticides are readily available in the thousands of small retail shops across the countryside, where unlicensed shop owners simultaneously sell household items, provide credit and act as pest control advisers. Insecticides being sold as FMCGs are not consistent with the principles of IPM or rational insecticide use.

Such practices are rare in countries where pesticide use is well regulated, like Australia and Europe, and such practices are in complete violation of the FAO-WHO International Code of Conduct on Pesticide Management (FAO/WHO 2014), formally endorsed by most Member States of the United Nations and the pesticide industry.

Furthermore, insecticide marketing is routinely driven by attractive product packaging, deceptive brand names, such as "Admire", "Macho", "Fastac", "Venom" and "Warhawk", and sales incentives, whereas IPM requires knowledge-based choices and rational decision-making. Calendar-based applications are favoured through insecticide marketing, which appeal to farmers as their use is not based on an in-depth knowledge of the pest or the ecosystem, whereas IPM requires a sound understanding of the local environment, the agricultural ecosystems, the biological cycles of the pests, the relations of natural enemies and ecosystems, and their services in pest control. IPM promotes the need for a scientific rationale based on technical knowledge of ecosystems to guide insecticide use, while insecticide marketing strategies focus on mass-scale consumer use to maximize profits.

Pesticide sale agents often enjoy handsome incentives, such as cash, household equipment, holiday trips and even sponsored trips to Mecca to perform the Haj, based on sales volume. As a result, in most Asian countries, pesticide sale agents far outnumber government officials trying to promote (more sustainable) pest management alternatives. For instance, in Thailand there are about 200 government extension officers, while the pesticide industry employs more than 35000 sales agents. 
Some extension agents might also earn extra cash from chemical companies by promoting the use of their insecticides. For instance, agricultural extension agents in China generate most of their salaries and office operating costs through pesticide sales (Hamburger 2002). In Viet Nam, extension staff often earn extra money by selling inputs to farmers and thus tend to bias the information they provide to farmers (McCann 2005).

\subsection{Acute Shortage of Pest Diagnostic Capacities and Professional Support to Farmers}

The shortage of skills among plant protection technician is another major constraint for the smooth implementation and further up-scaling of ecological engineering tactics. In most Asian countries, government budget cuts and a decreased emphasis on agriculture in college education has led to drastic reductions in the pest and disease diagnostic capacities of younger extension staff. Many assigned to plant protection duties are often incapable of recognizing pests and diseases or their symptoms, and thus are unable to advice farmers. Wrong information and advice can lead to increased unnecessary insecticide spraying. They also have poor knowledge of insecticides, their modes of action, application details and ecological methods.

More attention needs to be given on the development of interactive tools for extension workers who want to learn and diagnose pest, disease, and other problems that occur in rice, and how to manage them, such as the Rice Doctor (2019) and several smart phone apps now available.

\section{CONCLUDING REMARKS}

Most key insect pests of rice are monophagous or oligophagous, and thus highly dependent on rice for survival. They are $r$ strategists breeding in rice fields and migrating to invade new fields every season. The level of infestation in newlyestablished crops depends on the abundance of the immigrant populations and the generation survival rates.

In most cases rice farmers' insecticide applications have low and often negative productivity gains (Pingali et al. 1997; Heong et al. 2015c). Insecticide use, especially in the early crop stages, often used prophylactically or targeting leaf feeders, is unnecessary, has detrimental effects on ecosystem services, and promotes abnormal population growth and outbreaks of planthoppers (Heong 2009). The resulting high pest populations can readily invade neighbouring fields, where no insecticides are used, thus overwhelming resident natural enemy populations and inflicting huge damage and yield losses. In order to sustainably manage pest problems in rice production systems, area-wide perspectives and strategies are required. 
The ecological engineering approach can be effectively employed to build or restore ecosystem services in rice production systems. This approach involves three ecological strategies to improve pest suppression (Gurr et al. 2012). The first is to minimize mortality of beneficial arthropods by reducing insecticide use, especially in the early crop stages. The second is to support the build-up of predators in the early crop stages by providing alternative food sources such as non-pest prey items, like chironomids. Avoiding insecticide use in the first 40 days after sowing (Way and Heong 1994) will also enhance this second strategy. The third is to enhance hymenopteran parasitoids through habitat manipulation, like growing nectar-rich flowering plants on the bunds. Bund flowers provide nectar for food, thus benefiting a huge diversity of parasitoids and other natural enemies (Gurr et al. 2010). Egg parasitoids of planthoppers, for instance, increase their attack capacities when they feed on sesame flowers (Zhu et al. 2013).

There are several ways to encourage farmers to adopt ecological engineering and to conserve biodiversity and ecosystem services through insecticide reduction. In light of the shortage of extension staff with pest diagnostic skills and the need for an areawide adoption of pest management practices, communication strategies, such as multi-media campaigns and entertainment-education can be usefully employed to motivate farmers (Escalada and Heong 2012). Such strategic use of mass-media is relatively cheap, is able to reach tens of thousands of farmers at limited cost, in a short time and with frequent repetitions, and the resulting changes in behaviour can thus become sustainable. In addition, for area-wide pest management to be sustainable, pesticide management policies, especially those related to marketing, need to be in place, properly implemented and duly enforced.

As long as pesticide marketing tactics are not in compliance with the FAO-WHO Code of Conduct, and pesticides continue to be sold as FMCGs with numerous trade names in unlicensed retail outlets, it will be exceptionally challenging for nonpesticide management options, like ecological engineering or IPM, to be adopted sustainably.

Besides revising and enforcing pesticide marketing regulations, the enactment of environment-friendly laws will create the platform for ecological engineering techniques. In South Korea, for instance, the Environmentally Friendly Agriculture Promotion Act (EFA) was enacted and implemented in 1998 (Kim and Lim 2015). Under this Act, there were shifts in subsidies from chemical inputs to environmentfriendly alternatives, like growing other crops or plants. As a result, there was a transformation of the rice production landscape in South Korea with farmers growing sesame, soybeans and flowering plants around their rice crops. In addition to benefiting from the subsidy shifts, farmers were also able to market products from other crops, especially sesame and soybeans. The government also established the EFA Department with staff to implement the Act and provide assistance, such as seeds of other crops. 


\section{ACKNOWLEDGEMENTS}

The authors would like to thank the International Rice Research Institute (IRRI) where most of the work was carried out, and the Asian Development Bank (ADB) RETA 6489, and the Swiss Development Agency (SDC) for providing the funds for the research and networking activities, as well as the two anonymous reviewers for providing us with valuable suggestions.

\section{REFERENCES}

Bottrell, D. G., and K. G. Schoenly. 2012. Resurrecting the ghost of green revolutions past: The brown planthopper as a recurring threat to high-yielding rice production in tropical Asia. Journal of AsiaPacific Entomology 15: 122-140.

Escalada, M. M. and K. L. Heong. 2012. Using farmer surveys and sociological tools to facilitate adoption of biodiversity-based pest management strategies, pp. 199-213. In G. M. Gurr, S. D. Wratten, W. E. Snyder, and D. M. Y. Read (eds.), Biodiversity and insect pests: Key issues for sustainable management. John Wiley \& Sons, Ltd., UK.

Escalada, M. M., K. L. Heong, N. H. Huan, and V. Mai. 1999. Communications and behavior change in rice farmers' pest management: The case of using mass media in Vietnam. Journal of Applied Communications 83: 7-26.

Escalada, M. M., K. L. Heong, V. Sengsoulivong, and J. C. Schiller. 2006. Determinants of insecticide use decisions of lowland rice farmers in Laos, pp. 283-290. In J. C. Schiller, M. B. Champhengxay, B. Linguist, and S. Appa Rao (eds.), Rice in Laos. International Rice Research Institute, Los Baños Philippines.

Escalada, M. M., K. L. Heong, N. H. Huan, and H. V. Chien. 2009. Changes in rice farmers' pest management beliefs and practices in Vietnam: An analytical review of survey data from 1992 to 2007, pp. 447-456. In K. L. Heong, and B. Hardy (eds.), Planthoppers: New threats to the sustainability of intensive rice production systems in Asia. International Rice Research Institute, Los Baños, Philippines.

(FAO) Food and Agriculture Organization of the United Nations. 2011. Save and grow: A policymaker's guide to the sustainable intensification of smallholder crop production. FAO, Rome, Italy. $102 \mathrm{pp}$.

(FAO/WHO) Food and Agriculture Organization of the United Nations/World Health Organization. 2014. The international code of conduct on pesticide management. FAO, Rome, Italy. 37 pp.

Feder, G., R. Murgai, and J. B. Quizon. 2004. The acquisition and diffusion of knowledge: The case of pest management training in Farmer Field Schools, Indonesia. Journal of Agricultural Economics 55: $221-243$.

Fox, J. J. 2014. Fast-breeding insect devastates Java's rice. Asian Scientist, March 2014 issue.

Gurr, G. M., K. L. Heong, J. A. Cheng, and J. L. Catindig. 2012. Ecological engineering against insect pests in Asian irrigated rice, pp. 214-229. In G. M. Gurr, S. D. Wratten, W. E. Snyder, and D. M. Y. Read (eds.), Biodiversity and insect pests: Key issues for sustainable management. John Wiley \& Sons, Ltd., UK.

Gurr, G. M., J. Liu, D. M. Y. Read, J. L. A. Catindig, J. A. Cheng, L. P. Lan, and K. L. Heong. 2010. Parasitoids of Asian rice planthopper (Hemiptera: Delphacidae) pests and prospects for enhancing biological control. Annals of Applied Biology 158: 149-176.

Gurr, G. M., Z. X. Lu, X. S. Zheng, H. X. Xu, P. Y. Zhu, G. H. Chen, X. M. Yao, J. A. Cheng, Z. R. Zhu, J. L. Catindig, S. Villareal, H. V. Chien, L. Q. Cuong, C. Channoo, N. Chengwattana, P. H. Lan, L. H. Hai, J. Chaiwong, H. I. Nicol, D. J. Perovic, S. D. Wratten, and K. L. Heong. 2016. Multi-country evidence that crop diversification promotes ecological intensification of agriculture. Nature Plants 22 (2): 16014.

Hamburger, J. 2002. Pesticides in the People's Republic of China: A growing threat to food safety, public health and the environment. China Environment Series 5: 29-44.

Heinrichs, E. A. (ed.) 1994. Biology and management of rice pests. Wiley Eastern Ltd., New Delhi, India. 779 pp. 
Heong, K. L. 2009. Are planthopper problems due to breakdown in ecosystem services? pp. 221-232. In K. L. Heong, and B. Hardy (eds.), Planthoppers: New threats to the sustainability of intensive rice production systems in Asia. International Rice Research Institute, Los Baños, Philippines.

Heong, K. L., and M. M. Escalada (eds). 1997. Pest management of rice farmers in Asia. International Rice Research Institute, Los Baños, Philippines. 245 pp.

Heong, K. L., and B. Hardy (eds.). 2009. Planthoppers: New threats to the sustainability of intensive rice production systems in Asia. International Rice Research Institute, Los Baños, Philippines. 460 pp.

Heong, K. L., and K. G. Schoenly. 1998. Impact of insecticides on herbivore-natural enemy communities in tropical rice ecosystems, pp. 381-403. In P. T. Haskell, and P. McEwen (eds.), Ecotoxicology: Pesticides and beneficial organisms. Chapman and Hall, London, U.K.

Heong, K. L., G. B. Aquino, and A. T. Barrion. 1991. Arthropod community structures of rice ecosystems in the Philippines. Bulletin of Entomological Research 81: 407-416.

Heong, K. L., M. M. Escalada, and A. A. Lazaro. 1995. Misuse of pesticides among rice farmers in Leyte, Philippines, pp. 97-108. In P. L. Pingali and P. A. Roger (eds.), Impact of pesticides on farmers' health and the rice environment. Kluwer Press, San Francisco, USA.

Heong, K. L., M. M. Escalada, N. H. Huan, and V. Mai. 1998. Use of communication media in changing rice farmers' pest management in South Vietnam. Crop Protection 17: 413-425.

Heong, K. L., M. M. Escalada, N. H. Huan, V. H. Ky Ba, L. V. Thiet, and H. V. Chien. 2008. Entertainment-education and rice pest management: A radio soap opera in Vietnam. Crop Protection 27: $1392-1397$.

Heong, K. L., M. M. Escalada, N. H. Huan, H. V. Chien, and P, V. Quynh. 2010. Scaling out communication to rural farmers - Lessons from the "Three Reductions, Three Gains" campaign in Vietnam, pp. 207-220. In F. Palis, G. Singleton, and M. Casimero (eds.), Research to impact: Case studies for natural resources management of irrigated rice in Asia. International Rice Research Institute, Los Baños, Philippines.

Heong, K. L., M. M. Escalada, H. V. Chien, and L. Q. Cuong. 2014. Restoration of rice landscape biodiversity by farmers in Vietnam through education and motivation using media. In G. Mainguy (ed.), Special issue on large scale restoration of ecosystems. S.A.P.I.E.N.S (online) 7: (2) 29-35.

Heong, K. L., Cheng, J. A. and M. M. Escalada (eds.). 2015a. Rice planthoppers: Ecology, management, socio economics and policy. Zhejiang University Press, Hangzhou and Springer Science+Business Media Dordrecht. $231 \mathrm{pp}$.

Heong, K. L, L. Wong, and J. H. Delos Reyes. 2015b. Addressing planthopper threats to Asian rice farming and food security: Fixing insecticide misuse, pp. 69-80. In K. L. Heong, J. A. Cheng, and M. M. Escalada (eds.), Rice planthoppers: Ecology, management, socio economics and policy. Zhejiang University Press, Hangzhou and Springer Science+Business Media, Dordrecht, The Netherlands.

Heong, K. L., M. M. Escalada, H. V. Chien, and J. H. Delos Reyes. 2015c. Are there productivity gains from insecticide applications in rice production? pp. 179-190. In K. L. Heong, J. A. Cheng, and M. M. Escalada (eds.), Rice planthoppers: Ecology, management, socio economics and policy. Zhejiang University Press, Hangzhou and Springer Science+Business Media Dordrecht, The Netherlands.

Huan, N. H., L. V. Thiet, H. V. Chien, and K. L. Heong. 2005. Farmers' evaluation of reducing pesticides, fertilizers and seed rates in rice farming through participatory research in the Mekong Delta, Vietnam. Crop Protection 24: 457-464.

Huan, N. H., H. V. Chien, P. V. Quynh, P. S Tan, P. V. Du, M. M. Escalada, and K. L. Heong. 2008. Motivating rice farmers in the Mekong Delta to modify pest management and related practices through mass media. International Journal of Pest Management 54: 339-346.

(IRRI) International Rice Research Institute. 2013. Rice Almanac, 4th edition. International Rice Research Institute, Los Baños, Philippines. 283 pp.

Ives, A. R., and W. H. Settle. 1997. Metapopulation dynamics and pest control in agricultural systems. American Naturalist 149: 220-246.

Kraker, J. De, A. Van Huis, J. C. Van Lenteren, K. L. Heong, and R. Rabbinge. 1999. Egg mortality of rice leaffolders Cnaphalocrocis medinalis and Marasmia patnalis in irrigated rice fields. BioControl 44: 449-471.

Kim, C. G., and S. S. Lim. 2015. An evaluation of the environmentally friendly direct payment program in Korea. Journal of International Economic Studies 29: 3-22. 
Lu, Z. X., P. Y. Zhu, G. M. Gurr, X. S. Zheng, G. H. Chen, and K. L. Heong. 2015. Rice pest management by ecological engineering: A pioneering attempt in China, pp. 161-178. In K. L. Heong, J. A. Cheng, and M. M. Escalada (eds.), Rice planthoppers: Ecology, management, socio economics and policy. Zhejiang University Press, Hangzhou and Springer Science+Business Media, Dordrecht, The Netherlands.

Lu, Y. H., K. Liu, X. S. Zheng, and Z. X. Lu. 2017. Electrophysiological responses of the rice striped stem borer Chilo suppressalis to volatiles of the trap plant vetiver grass (Vetiveria zizanioides L.). Journal of Integrative Agriculture 16(11): 2525-2533.

Matteson, P. C. 2000. Insect pest management in tropical Asian irrigated rice. Annual Review of Entomology 45: 549-574.

(MEA) Millennium Ecosystem Assessment. 2005. Ecosystems and human well-being: Synthesis. Island Press, Washington, DC, USA. 155 pp.

McCann, L. 2005. Transaction costs of agri-environmental policies in Viet Nam. Society and Natural Resources: An International Journal 18: 759-766.

Pingali, P. L., M. H. Hossain, and R. Gerpacio. 1997. Asian rice bowls: The returning crisis? International Rice Research Institute, Los Baños, Philippines and CABI International, Wallingford, UK. $341 \mathrm{pp}$.

Rice Doctor 2019. Interactive tool for extension workers, students, researchers and other users who want to learn and diagnose pest, disease, and other problems that can occur in rice; and how to manage them.

Simon, H. A. 1982. Models of bounded rationality: Empirically grounded economic reason. Volume 3. MIT Press, Cambridge, Massachusetts, USA. 336 pp.

Singhal, A., and E. M. Rogers. 1999. Entertainment-education: A communication strategy for social change. Lawrence Erlbaum Associates Publishers, Mahwah, New Jersey, USA. 280 pp.

Spangenberg, J. H., J. M. Douguet, J. Settele, and K. L. Heong. 2015. Escaping the lock-in of continuous insecticide spraying in rice: Developing an integrated ecological and socio-political DPSIR analysis. Ecological Modelling 295: 188-195.

Thorburn, C. 2013. Empire strikes back: The making and unmaking of Indonesia's national Integrated Pest Management program. Agroecology and Sustainable Food Systems 38: 3-24.

Watanabe, T., M. Matsumura, and A. Otuka. 2009. Recent occurrences of long-distance migratory planthoppers and factors causing outbreaks in Japan, pp. 179-190. In Heong, K. L. and B. Hardy (eds.), Planthoppers: New threats to the sustainability of intensive rice production systems in Asia. International Rice Research Institute, Los Baños, Philippines.

Way, M. J., and K. L. Heong. 1994. The role of biodiversity in the dynamics and management of insect pests of tropical irrigated rice - A review. Bulletin of Entomological Research 84: 567-587.

Zheng, X., Y. Lu, P. Zhu, F. C. Zhang, J. Tian, H. Xu, G. Chen, C. Nansen, and Z. Lu. 2017. Use of banker plant system for sustainable management of the most important insect pest in rice fields in China. Scientific Reports 7: 45581.

Zhu, P. Y., G. M. Gurr, Z. X. Lu, K. L. Heong, G. H. Chen, X. S. Zheng, H. X. Xu, and Y. J. Yang. 2013. Laboratory screening supports the selection of sesame (Sesamum indicum L.) to enhance Anagrus spp. parasitoids (Hymenoptera: Mymaridae) of rice planthoppers. Biological Control 64: 8389. 